\title{
Diversity Training and its Impact on the Employees' Organizational Commitment: Job Satisfaction as a Moderating Variable in the Classic Fashion Apparel Industry Company
}

\author{
Rokaya AL-Badareen ${ }^{1} \&$ Hadeel Al-Ghazzawi ${ }^{1}$ \\ ${ }^{1}$ Jadara University, Jordan \\ Correspondence: Rokaya AL-Badareen, Jadara University, Jordan. E-mail: Rokaya@jadara.edu.jo
}

Received: July 11, 2018

Accepted: August 6, 2018

Online Published: September 6, 2018

doi:10.5539/ijbm.v13n10p116

URL: https://doi.org/10.5539/ijbm.v13n10p116

\begin{abstract}
The purpose of this study is to examine the impact of diversity training on the organizational commitment and also identify the role of job satisfaction in improving the relationship between diversity training and organizational commitment of the employees. For this purpose, the data gathered from (110) individuals operating in Classic Fashion Apparel Industry Company in Jordan have been analyzed, applying statistical techniques and methods. The analysis of the research data has revealed that the diversity training had a positive impact on the organizational commitment of employees. The research data has also indicated that the job satisfaction, as a Moderating Variable, had a meaningful role in improving the relationship between diversity training and organizational commitment.
\end{abstract}

Keywords: diversity training, job satisfaction, organizational commitment, classic fashion apparel industry company, Jordan

\section{Introduction}

commitment is considered one of the most important human phenomena since the beginning of the creation since it was the focus of all religions; Quran, in many verses, focused on the content of commitment where God describes those who fulfilled the promises with honesty as is it in this verse: "...[those who] fulfill their promise when they promise; and [those who] are patient in adversity and hardship and during battle. Those are the ones who have been true, and it is those who are the righteous." (Al-Baqarah, p. 177). Our Arab and Islamic history presents various incidents showing the importance of commitment and the consequences of its weakness or loss. It can be said that one of the main reasons for the defeat of Muslims in Uhud battle is the weak commitment of some Muslims who were entrusted to protect the army in accordance with the instructions of the Prophet Muhammad (peace and blessings of Allah be upon him).

The attention towards the organizational commitment started, as (Al-Qasim, 2012) has stated, from the beginning of the second half of the twentieth century until the present. The importance of the organizational commitment comes from being a vital element in achieving the organizational objectives and enhancing creativity, reliability and trust between the management and its employees. The organizational commitment contributes to the development of the organization's abilities for sustainability and growth (Hanounah, 2006). Due to the fact that having a committed workforce has become an urgent necessity for every organization operating in today's highly complicated environment and the fact that most organizations are spending a large amount of financial resources to get and maintain the committed workforce, it became imperative for organizations to work on identifying the most important factors which can affect the employees' organizational commitment; one of such factors is the job satisfaction. This means that organizations must work on taking all the necessary procedures enabling them to satisfy the needs of employees in a way that increases their job satisfaction level leading to more organizational commitment(Sohail, et al., 2011).

Diversity training is one of the most important practices used by the human resources departments to reduce the negative impacts of the workforce diversity. Due to the fact that such type of training makes employees more effective and aware of issues related to diversity since it helps improve the interaction between the managers and employees, among employees themselves and between employees and customers, and due to the fact that such 
type of training makes employees own more skills that enable them to deal with different cultures and different performance Patterns (Sohail et al., 2012).

Because the importance of the diversity training in increasing the employees' organizational commitment, especially at the companies that have a varied workforce, this study emerged to examine the impact of diversity training on organizational commitment of the employees, and the role of the job satisfaction in improving the impact of the diversity training on the organizational commitment of the employees.

\section{Literature Reviews}

\subsection{Diversity Training}

(Kalinoski, et. al, 2013) stated that the diversity training is one of the most important methods enabling the international companies to survive and achieving their goals; many of these companies have paid a part of their annual budget to spend on training in general, and the diversity training in particular. This type of training is no longer considered limited to expenses and costs but it is a huge investment in the human capital, an investment that will later be accomplished by achieving their organizational goals and increasing their competitiveness. It can be said that the diversity training is different from the rest of the kinds of training because it includes a kind of challenge for the employee's perspective towards the world around him, and addresses issues that can be described as emotional and personal. Since the employees' attitudes about diversity form before the implementation of this type of training, therefore, we find that the diversity training tends to focus on the emotional and cultural aspects. (Jackson, 2017) defined the diversity training as a set of methods used by the human resources management to train the employees to manage the differences among the members of the organization by identifying these differences and adapting them to the benefits of the organization. (Lindsey, et. al., 2015) mentioned that the diversity training represents the processes of the effective training for the local and expatriate employees to achieve the full perfection of the performance of the assigned duties. (Bezrukova \& Jehn \& Spell, 2012) stated that the diversity training is a set of programs designed to facilitate the positive interaction, reduce the discrimination and intolerance at the work groups, increase the level of the skills and knowledge of the employees, and increase their motivation to deal with the diversity of others.

The companies need the diversity training for the following reasons (Mursi, 2010; Bezrukova, Jehn \& Spell, 2012):

- $\quad$ The expatriate employees need training to deal with the culture of the host country.

- The local employees at the multinational companies need training for the new cultural patterns, whether they were related to the company or coming from the mother country.

- In general, the employees in the multinational companies need training for working in a multinational environment, which will lead to more diverse job values and attitudes, employees' aspirations, social experiences, and the elements of the culture that influences the organizational performance.

- Both managers and employees at the multinational companies need training for some aspects of culture in the host country and the company, which are related to work such as: customs laws, labor laws, customs of media or languages, or the codes of conduct within the work environment.

\subsection{Job Satisfaction}

Some experiments and studies asserted that the success of many successful organizations is attributed to the presence of a developed management that cares about the interests and problems of employees and uses the latest techniques and methods to improve the employees' satisfaction and performance. It is well known that the success of any organization is measured by the qualification of the potential energy of employees to be embodied in high levels of giving (Zwiesh, 2104). Therefore, writers and researchers work hard to understand the job satisfaction and the factors that influence it due to its great role in maintaining the employees of the organization, especially those who have creative skills and abilities that enable the organization to achieve the required competitive advantage. The job satisfaction expresses the viewpoints of employees regarding their job, which depends on many factors, some of which are related to the core of the job design (Intrinsic), and some are related to the external job environment (Extrinsic) (Abu Elnaga, 2012). Foroughi et al. (2014) defined the job satisfaction as "an effective variable that results from the individual's assessment of his or her experiences or attitudes." Na_Ann and Pukkeeree (2013) also indicated that the job satisfaction is the attitude carried by individuals towards their job which created a perception about the level of achieving the job as well as the level of correlation between the individual and the organization in which he works.

Saleem, Mahmood \& Mahmood, (2010) stated that the job satisfaction represents the case resulting from an 
individual's assessment of the extent of meeting his psychological needs by the job environment (Huwaihi, 2008) divided the satisfaction into:

1. The internal satisfaction, which is achieved through performing the job, sense of accomplishment and self-achievement, and the pleasure gained from performing the job.

2. External satisfaction, which refers to the satisfaction achieved through the support and rewards given to the individual by the organization or supervisor financially or psychologically.

3. General satisfaction, which includes both the internal and external satisfaction.

\subsection{Importance of Job Satisfaction}

The importance of the job satisfaction at organizations increased because of its role in increasing the ability of individuals to adapt to the job environment, increasing their willingness to innovate, increasing their level of ambition and development, raising the morale of employees and increasing their loyalty to the organization and making the individuals more alert during performing their job, which contributes in decreasing the work accidents they might face; furthermore, there is a strong relationship between the job satisfaction and the production at work; the higher the degree of satisfaction, the higher the production, and the more distinguished performance of the organization in achieving a distinct, competitive position in the market (Azion, 2007; Al-Dosari, 2010; Yousef, 2010; Mubarki, 2014; Zwiesh, 2014).

\subsection{Organizational Commitment}

The organizational commitment is one of the topics that have received more attention in the recent decades due to its clear impact on the organization's effectiveness and its direct role in increasing the employees' loyalty to the organization and getting more cohesive and participatory work teams in knowledge, experience, which can achieving an outstanding performance (Leite, et al, 2014). In addition, the organizational commitment enables organizations to avoid many economic, social and psychological costs at the individual and group levels. (Al-Enzi and Al-Zubaidi, 2006; Khair Al-Din and Al-Najjar, 2010). (Al-Baqmi, 2012) stated that the organizational commitment represents the degree of correlation between the individual and the organization and that it represents a strong acceptance of the organization's goals and values by the employees as well as the desire to stay in this organization for a long term. (Meyer \& Allen, 1993) divided the organizational commitment of the employees into:

1. Affective commitment, it expresses the emotional aspect stemming from the employee towards his organization, who is influenced by the employee's understanding of the distinctive characteristics of his work such as his natural relationship with supervisors and the acquired skills (Khair Al-Din and Al-Najjar, 2010).

2. Continuous commitment, This type of commitment reflects the employee's desire in insisting to work within the organization and his inability to sacrifice it (Al-Sirafi, 2005).

3. Normative commitment, This type expresses the moral and personal commitment shown by the employee by adhering to the values and goals of the organization; such feeling is strengthened by the good support of the organization for its employees, allowing them to participate and interact positively not only in the implementation of the job but also in contributing to the development of goals, planning and policy-making of the organization (Hassan, 2006).

\subsection{Statement of the Problem}

If the human being is the engine of any human activity, the success of business organizations, as indicated by some studies, depends primarily on the attitudes and behavior of their human resource(Balfaqih, 2012). Because the organizational commitment is considered one of the most significant organizational behavioral variables, it received the attention of many researchers and scholars in the management science. It is an intangible behavior stemming from the individual's self, which can be touched by his behavior represented in his loyalty and belonging to the organization in which he works and working hard on spending the time and effort required for success; the recent history asserted that the economic growth achieved by the developed countries, especially Germany and Japan, goes to a committed workforce that $90 \%$ of the success of the Japanese organizations is due to the organizational commitment (Flambain, 2008).

Despite the importance of the organizational commitment in the organization's achievement of objectives, there are some factors which, if not taken into consideration, will negatively affect the employees' organizational commitment, most important of which is the job satisfaction. Chester Bernard, one of the first thinkers of management, in his theory of the balance between contribution and satisfaction, stated that the higher the returns the employee expected or received from his job, the higher the incentive towards work and the higher his job 
satisfaction. Accordingly, the organizational commitment increases since it is one of the behavioral outputs that result from the employee's job satisfaction (Al-Sawaf, 2008). Among the factors that may have a negative impact on the organizational commitment may also be the issue of the workforce diversity, which has emerged largely as a result of the emergence of globalization and the multinational companies. Sohail et al. (2011) and Yap et al. (2010) indicated that the diversity workforce suffer more from the low level of the job satisfaction and the organizational commitment than the homogeneous working groups, which is attributed to the fact that the diversity among employees leads to an increase in the personal conflicts among them, expatriates and minorities usually have bad relations with their managers like not getting the promotion opportunities they deserve, or they are assigned in jobs that are unsuitable with their abilities and potential. Although some organizations have resorted to certain practices to eliminate the negative impact of the workforce diversity on both the job satisfaction and the organizational commitment of employees, most important of which is the so-called diversity training; however, this type of training, despite its wide expansion at various organizations, its effectiveness is still the subject of debate and uncertainty in terms of its ability to help organizations to benefit from the advantages of the workforce diversity and minimize the negative impacts that might be resulted from this diversity on the behavioral outcomes and performance of employees.

\subsection{Study Objectives}

The objectives of this study was to:

1. Determine the impact of the diversity training on the organizational commitment of the employees.

2. Determine the extent to which the job satisfaction play meaningful role in improving the impact of diversity training in the organizational commitment of the employees.

\subsection{Study Hypotheses}

The impact of the human resource management practices, especially the diversity training on the behavioral outcomes of employees, such as the job satisfaction and the organizational commitment, attracted many researchers such as (Gilliard, 2008; Yap, Holmes \& Cukier, 2010; Sohail et al., 2011 King, et.al,2012; Balfaqih,2012; Law, 2012; Akinyi, 2014; Khalid \& Khalid, 2015; Hassan \& Mahmood, 2016). Manjuri (2012) stated that many companies moved towards globalization and these companies, especially multinational ones, have become owning about half of the world's assets, which in turn increased the workforce diversity in such companies in terms of race, religion, gender and knowledge as well as increasing the proportion of employees under the age of thirty years, and those over the age of fifty-five years old. Despite the fact that the workforce diversity, as mentioned by (Zarzoor, 2015), might lead to more creative capacity and organizational performance at the organizations; if such diversity was not managed through practices that help the organization create a common identity, this will lead that the employees feel inequality leading to a higher level of organizational conflict, which will negatively affect their behavioral outcomes, most important of which are the employees organizational commitment they would show towards their organizations.

Punia \& Kant (2013) stated that the degree to which any training process attains the desired objectives or immediately expected results, which called 'Training Effectiveness" is depend on many factors. Tai (2006); Saks and Haccoun (2007) discussed that psychological states of trainees especially motivation, self-efficacy, affects the training outcomes represents an important factors in improving the effectiveness of training outcomes which represented as mentioned in Kirkpatrick's (1967) hierarchical model of training outcomes in behavior change and improvements in individual or organizational outcomes such as turn- over, accidents, organizational commitment or productivity. Gouws (1995) defined motivation as an inner wish or urge that originates with an individual, either consciously or unconsciously, to complete a task successfully because it is enjoyable, and not necessarily for what will be received in return. Motivation can also be seen as that internal drive that causes an individual to decide to take action and to It is also the level of energy, commitment and creativity(Ogunnaike \& Akinbola, 2014). Employee motivation and job satisfaction become crucial elements in achieving success in any organizational process. Extensive research has shown that employee motivation and job satisfaction are not brought about in isolation, and the perceived job satisfaction creates positive feelings among employees, which in turn, represents positive emotional reaction and increasing their motivation towards accomplishing any activities related to their jobs (Roos, 2005; Ogunnaike \& Akinbola, 2014). In spite of many studies that have concluded the presence of a relationship between the organizational commitment and the job satisfaction such as Al-Qudah, (2010); Chiu (2011); Khalid and Khalid, (2015). And the studies concluding the presence of an impact for the diversity training on the job satisfaction and the organizational commitment, including (Yap Holmes \& Cukier, 2010), which showed that individuals who were examined in the organizations adopting the diversity training effectively were more commitment and satisfied in their jobs than their peers who worked in 
organizations practicing ineffective diversity training (Sohail, et al., 2011), which found out that there was a positive impact for the diversity training on the organizational commitment, job satisfaction, and creativity. However, all the previous studies being referred to did not try to examine the role of the job satisfaction as a moderator for the relationship between the diversity training and the organizational commitment. On this basis, followings are the main hypotheses in this study:

H01: There is no meaningful impact for the diversity training on the organizational commitment of the employees.

H02: There is no meaningful role for the job satisfaction in improving the relationship between the diversity training and the organizational commitment of the employees.

\section{Research Methodology}

The present study is descriptive -surveying research and applied method. population studied in this research is all the employees in the three top managerial levels: high, middle and low at Classic Fashion Apparel Industry Company in Jordan. The total number of this population was (110) individuals. The tools for gathering data was a closed questionnaire (based on Likert's five-item range) and its reliability and validity were established before the distribution, the reliability of diversity training questionnaire was 0.93 , the reliability of job satisfaction questionnaire was 0.77 and the reliability of job satisfaction questionnaire was 0.84 .

In order to analyze the data collected in this study and test its hypotheses, a set of statistical methods included in the SPSS were used, such as: the means and the standard deviations to identify the approval degree of the respondents regarding the study variables and dimensions, The following gradation was the criterion adopted by the researchers to judge the mean for the answer of the respondents on the items of the questionnaire:

A - The mean between 1- 2.33 reflects a low approval degree.

B- The mean between 2.34 - 3.66 reflects a moderate approval degree.

C- The mean between 3.67-5 reflects a high approval degree.

The correlation matrix, the simple regression coefficient, and the multiple regression were used to test the validity of the hypotheses related to the impact of the independent variable on the dependent variable, and the role of the moderator variable in improving this impact.

\section{Data Analysis}

Means and standard deviations were extracted in this study to identify the level of practicing the diversity training in the Classic Fashion Apparel Industry Co, the level of the job satisfaction and the organizational commitment for the employees in this company by asking the examined individuals to answer the items related to the practicing of the diversity training, the level of job satisfaction and the organizational commitment found in the questionnaire (Appendix 1). The results of the analysis, as shown in Table 2, showed that the mean for the approval of individuals at practicing of the diversity training in the company was (3.38) by a moderate approval degree and a standard deviation of (0.69). The mean for the approval of individuals at the job satisfaction of the employees was (3.13) by a moderate approval degree and a standard deviation of $(0.60)$. As for the level of the organizational commitment for the employees, the mean was (3.49) by a moderate approval degree and the standard deviation was (0.66).

Table 2. Means and standard deviations for the level of practicing the diversity training, level of job satisfaction and organizational commitment of employees

\begin{tabular}{lllll}
\hline no. & Variable & mean & Standard Deviation & Rating \\
\hline 1 & Level of practicing the diversity training & 3.38 & 0.69 & Moderate \\
3 & Level of job satisfaction & 3.13 & 0.60 & Moderate \\
2 & Level of Organizational Commitment & 3.49 & 0.66 & Moderate \\
\hline
\end{tabular}

We also estimate the correlation matrix for all the key variables used in this analysis. The correlation matrix presented in table 3 indicates a high degree of correlation among the variables considered in this study. Yet, the matrix indicates no issue for multicollinearity as all the correlation values are below 0.7 . 
Table 3. The correlation matrix

\begin{tabular}{llll}
\hline & Organizational commitment & Training Diversity & Job satisfaction \\
\hline Organizational commitment & 1 & & \\
Training Diversity & $.436^{* *}$ & 1 & \\
Job satisfaction & $.641^{* *}$ & $.579^{* *}$ & 1 \\
\hline
\end{tabular}

To examine the impact of the diversity training on the organizational commitment of the employees, the researchers used the single linear regression to test the validity of the first hypothesis the results of the regression test as shown in Table 4 indicated that there is a relationship between the diversity training and the organizational commitment of the employees which was 0.43 . Through calculating the $\mathrm{R}^{2}$, the researchers found that the diversity training accounted for $19 \%$ of the variance in the organizational commitment. Due to the fact that the $\mathrm{F}$ value was 22.67 and its statistical significance was 0.000 , this meant that the regression was significant at $(\alpha \leq$ 0.01 ). Accordingly, we can state that there was a meaningful impact for the diversity training on the organizational commitment of the employees.

Table 4. Results of the simple regression test of the impact of the diversity training on the organizational commitment of the employees at the Classic Fashion Apparel Industry Co

\begin{tabular}{lllllllll}
\hline independent variable & $(\beta)$ value & $(\mathrm{T})$ value & $\mathrm{Sig}$ & $\mathrm{R}$ & $\mathrm{R}^{2}$ & $\mathrm{Df}$ & $(\mathrm{F})$ value & $\mathrm{Sig}$ \\
\hline Diversity Training & 0.43 & 4.76 & 0.00 & 0.43 & 0.19 & 1 & 22.67 & 0.00 \\
\hline
\end{tabular}

To estimate the moderating role played by Job satisfaction as stated in the second hypothesis, we create a new model that accounts for the effect of the interaction term between Job satisfaction and Diversity training on Organization commitment. This in line with recommendation from Hair, Black, Babin, and Anderson, (2010); Alsaad, Mohamad, and Ismail $(2017 ; 2018)$. As shown in Table 5, the interaction term is positive and significant $(\beta=1.18$, p-value $\leq 0.01)$, indicating that a high level of Job satisfaction would improve the relationship between Diversity training and Organizational commitment. We look further to the change in the adjusted $\mathrm{R}^{2}$ as compared with the previous model (see Table 4) to estimate the magnitude of the explained variance by adding the interaction term to the model. As compared to the previous model, the adjusted $\mathrm{R}^{2}$ increases from 0.19 to 0.41 , indicating that the interaction term between Job satisfaction and Diversity training considerably improve the variance of Organizational commitment. Accordingly, we can conclude that job satisfaction significantly moderates the relationship between Diversity training and Organizational commitment which confirms H2.

Table 5. Results of the moderating effect of Job satisfaction in the relationship between diversity training and organizational commitment of the employees at the Classic Fashion Apparel Industry Co

\begin{tabular}{llllllll}
\hline independent variable & $(\beta)$ value & $(\mathrm{T})$ value & $\mathrm{Sig}$ & $\mathrm{R}$ & Adjusted $\mathrm{R}^{2}$ & $\mathrm{~F}$ value & $\mathrm{Sig}$ \\
\hline $\begin{array}{l}\text { Diversity Training } \\
\text { Interaction term }\end{array}$ & -0.640 & -3.59 & 0.00 & & & & \\
(Job satisfaction $\times$ Diversity training) & $\mathbf{1 . 1 8}$ & $\mathbf{6 . 6 2}$ & $\mathbf{0 . 0 0}$ & 0.65 & 0.41 & 39.7 & 0.00 \\
\hline
\end{tabular}

\section{Discussion of the Results}

The results of this study showed that the level of practicing the diversity training at the examined company was moderate, which means that the level of practicing was not at the level required for helping the company to take advantage of the diversity among its employees and direct this diversity towards increasing the creative abilities of its employees and increasing the employees' understanding of the others' culture, which reduces the likelihood of the conflicts, and raises the level of cooperation between them; the reason might be, as indicated in the individuals' answers to the items in the questionnaire, the lack of the managers' sufficient interest to this type of training and the lack of trainers who have the required skills and knowledge to implement this type of training programs. The current study also found that the level of the job satisfaction of the employees was moderate, which means that the feeling of the job satisfaction by the individuals in the examined company was not at the level required to increase the positive behaviors among employees, among which the organizational commitment is considered the most important. This might be attributed to, as it is evident in the answers of the respondents, 
the lack of the sufficient opportunity for employees to participate in the decision-making process regarding their jobs, lack of sense of justice required in terms of salaries and incentives compared to their efforts at the job, lack of feeling of equality in distributing the additional job tasks and providing the required appreciation by the management for their efforts. This was consistent with (Al-Qudah, 2010; Al-Shwabkeh \& Al-Taani, 2013) which stated that the level of the employees' job satisfaction was moderate.

The results of the present study also concluded that the level of the organizational commitment of the employees was moderate indicating that the level of the organizational commitment did not reach the desired level; this might be due to the fact that the employees' job satisfaction in the company, as shown by the results was not at the required level. Furthermore, the company management was not interested sufficiently in applying the training programs enabling them to benefit from such diversity, cancel the cultural barriers leading to a common understanding among them, increase cooperation between them, share the knowledge that raises the level of their performance as work teams, and increase their organizational commitment. The result was consistent with (Al-Nassafi, 2016), which stated that the level of the organizational commitment of employees was moderate; however, it was inconsistent with (Hanounah, 2006; Al-Qudah, 2010; Al-Shwabkeh \& Al-Taani, 2013) who stated that the level of the organizational commitment of the employees was high.

As for the impact of the diversity training on the organizational commitment, the current study showed that there was an impact for the diversity training on the organizational commitment; it was consistent with (Sohail et al, 2011; Yap, Holmes \& Cukier, 2010; Hassan \& Mahmood, 2016; Akinyi, 2014), which showed that there was an impact for the practices of the human resources management, especially the diversity training on the organizational commitment of employees. The present study also concluded that the job satisfaction played a meaningful role in improving the impact of the diversity training on the organizational commitment of employees.

\section{Conclusions}

The current study achieved its objectives in examining the impact of the diversity training on the organizational commitment and the role of the job satisfaction in improving the impact of this type of training on the organizational commitment of the employees. The results indicated the following:

1. The level of practicing the diversity training at the Classic Fashion Apparel Industry Co was moderate.

2. The level of the job satisfaction and the organizational commitment of the employees who were subject to the study was moderate.

3. There is a meaningful impact for the training diversity on the organizational commitment of the employees.

4. There is a meaningful role for the job satisfaction in improving the relationship between the diversity training and the organizational commitment of the employees.

\section{Recommendations}

Based on the results of the current study, the followings are suggested

1. Increasing the attention and interests of the management at the company in the training programs related to the workforce diversity through selecting designers of diversity training programs with wide experience in workforce diversity, providing such programs with sufficient information on the values, customs and traditions of the Jordanian community, changing the content of the training material of the diversity training programs in light of the training needs of their employees, explaining the objectives and requirements of the training program for trainees, and following up the complaints submitted by trainees to the trainers on their diversity training programs.

2. The need to raise the level of the job satisfaction among the employees of the company by providing them with the opportunity to participate in making the decisions related to their job tasks, taking into account the principle of equal opportunity in the promotion process, and distribution of rewards and incentives fairly according to the performance of the individuals, reconsidering the salaries paid in a way that is commensurate with the living costs and with the individuals' qualifications, abilities, and skills, and improving the communication system within the company.

3. Working on developing the organizational commitment among the employees of the company through providing an organizational environment that allows for innovation and creativity which is characterized by respect and appreciation relations among the employees. Also, it recommends linking the concept of the organizational commitment with well-designed standards and practices that are integrated with the incentive system with the criteria of quality, efficiency and active performance of work tasks. 
4. Strengthening the organizational commitment among the employees of the company through seminars and workshops whose focus is promoting the positive practices of the employees to serve the company's objectives and plans.

5. Conducting future studies on the variables studied at the companies in other sectors, such as the commercial or service sector, attempting to study the impact of diversity training on other behavioral outcomes like the employees' engagement, organizational citizenship behavior, turnover, conflict management, or teams' cohesion or attempting to take another moderator such as the leadership style, or the administrative empowerment.

\section{References}

Akinyi, O. (2014). The effect of human resource development on employee organizational commitment in commercial bank in Mombasa country, Kenya. Master thesis. University of Nairobi, Kenya.

Al-Baqmi, S. (2012). Organizational commitment and its relation to the functional performance of employees at the passports centers of Makkah region, Master Thesis, Naif Arab University for Security Sciences, Riyadh, Saudi Arabia.

Al-Dosari, M. (2010). The work stresses and their relationship to job satisfaction, survey study on the sub-stations border guards' staff in Al-Madinah Al-Munawarah area. Master Thesis, Naif Arab University for Security Sciences, Riyadh, Saudi Arabia.

Al-Enzi, S., \& Al-Zubaidi, G. (2006). The relationship of the organizational commitment with the employees' participation and its impact on achieving the requirements of quality to the human resources: A theoretical approach. Journal of Administration and Economics, 61, 125.

Al-Najjar, F., Al-Najjar, N., \& Al-Zuabi, M. (2013). Scientific research methods: Applied perspective, Jordan. Amman: Al-Hamed House for Publishing and Distribution.

Al-Nassafi, N. (2016). The impact of the organizational commitment on improving the outputs of the accounting information systems in the Kuwaiti public shareholding companies, Master Thesis, Al-Bayt University, Mafraq, Jordan.

Al-Qasim, R. (2012). The impact of the organizational commitment on improving the quality of the banking service. Master thesis, Middle East University, Amman, Jordan.

Al-Qudah, A. (2010). The Job satisfaction and its relation to the organizational commitment from the perspective of the nursing staff at the Jordanian government hospitals: Field study, Irbid Governorate, Master Thesis, Irbid, Jordan.

Alsaad, A., Mohamad, R., \& Ismail, N. A. (2018). The contingent role of dependency in predicting the intention to adopt B2B e-commerce. Information Technology for Development, 1-29. http://doi.org/10.1080/02681102

Al-Sawaf, M. (2008). Job leakage: Definition, causes, and consequences through an application on the technical maintenance sector in the general organization of Saudi Arabian Airlines in Jeddah. Master Thesis, King Abdulaziz University, Jeddah, Saudi Arabia.

Al-Shwabkeh, A., \& Al-Taani. H. (2013) Job satisfaction and its relation to the organizational commitment of employees in Jordanian public universities. Educational Science Studies, 40(1), 181-200.

Al-Sirafi, M. (2005). Organizational behavior, Alexandria: Hawras for publishing.

Azion, Z. (2007). Stimulation and its impact on the job satisfaction of the human resources in the economic institution: Numidia unit, Constantine as a case study, Master Thesis, Skikda University, Algeria.

Balfaqih, A. B. (2012). The impact of the human resources management practices on the organizational commitment: Field Study in the private hospitals in Yemen, Master Thesis, Al-Bayt University, Mafraq, Jordan.

Bezrukova, K., Jehn, K., \& Spell, C. H. (2012). Reviewing diversity training: Where we have been and where we should go. Academy of Management Learning \& Education, 11(2), 207-227.

Chiu, W. (2011). Job satisfaction and organizational commitment amongst quantity surveyors in Hong Kong: an attitudinal perspective. Master Thesis. University of Hong Kong, Pokfulam, Hong Kong. http://dx.doi.org/10.5353/th_b5137945

Elrehail, H., Lawrence, O., Alsaad, A., \& Alzghoul, A. (2018). The impact of Transformational and Authentic leadership on innovation in higher education: The contingent role of knowledge sharing. Telematics and 
Informatics, 35(1), 55-67. http://doi.org/10.1016/j.tele.2017.09.018

Flambain, E. (2008). Job satisfaction and its relation to the organizational commitment of the male and female educational supervisors in the department of education in Makkah City, Master Thesis, Umm Al Qura University, Saudi Arabia.

Foroughi, M., Peiravian, F., Naderi, A., \& Rajabzadeh, H. R. (2014).An Analysis of Job Satisfaction among Iranian Pharmacists through Various Job Characteristics. Iranian Journal of Pharmaceutical Research, 13(3), 1087-1096.

Gilliard, J. (2008). Diversity training: A study of the impact of diversity training on organizational performance, financial results and accountability. Retrieved from https://search.proquest.com/openview/9be94981aae4b2cfe96cc15df34d5932/1.pdf?pq-origsite=gscholar\&c $\mathrm{bl}=18750 \&$ diss $=\mathrm{y}$

Gouws, A. (1995). The relationship between motivation and job satisfaction of a group of information specialists. doctoral dissertation, Rand Afrikaans University, Johannesburg.

Hair, J. F., Black, W. C., Babin, B. J., \& Anderson, R. E. (2010). Multivariate Data Analysis: A global perspective.

Hanounah, S. (2006). Measuring the level of the organizational commitment among the employees at the Palestinian Universities in the Gaza Strip, Master Thesis, Islamic University, Gaza.

Hassan, K. (2006). leadership types for the head of departments and their impact on the organizational commitment-An exploratory study for the viewpoints of a sample of the teaching staff at the Faculty of Education / Al-Qadisiya University. Retrieved from https://iasj.net/iasj?func=fulltext\&aId=12208

Hassan, S., \& Mahmood, B. (2016). Relationship between HRM practices and organizational commitment of employees: An empirical of textile sector in Pakistan. International Journal of Academic Research in Accounting, Finance and Management Sciences, 6(1), 23-28.

Huwaihi, M. (2008). The impact of the factors causing the job satisfaction on the desire of the employees of proceeding the job: Case study on the Health Job Committees in the Gaza Strip. Master Thesis, Islamic University, Gaza.

Jackson, Sh. (2017). The key to successful diversity training is creativity and flexibility. Insight into Diversity, 88(4), 26-28.

Kalinoski, Z., Steele-Johnson, D., Peyton, E., Leas, Keith, A., \& Steinke, \& Julie, B. (2013). A meta-analytic evaluation of diversity training outcomes. Journal of Organizational Behavior, 34(8), 1076-1104.

Khair Al-Din, M., \& Al-Najjar, M. (2010). The impact of the internal environment on the organizational commitment at the General Organization for the Social Security in the Hashemite Kingdom of Jordan: Field study. Retrieved from https://www.google.jo/search?q

Khalid, A., \& Khalid, S. (2015). Relationship between organizational commitment, employee engagement and career satisfaction: A case of university of Gujarat, Pakistan. Journal of South Asian Studies, 3(3), 323-330.

King, E., Dawson, J., Kravitz, D., \& Gulick, L. (2012). A multilevel study of the relationships between diversity training, ethnic discrimination and satisfaction in organizations. Journal of Organizational Behavior, 33(1), $5-20$.

Kirkpatrick, D. (1976). Evaluation of training, training and development handbook: A guide to human resource development. New York; McGraw-Hill Company.

Law, Ch. (2012). When diversity training isn't enough: The case for inclusive leadership.

Leite, N., Rodrigues, A., \& Albuquerque, L. (2014). Organizational Commitment and Job Satisfaction: What Are the Potential Relationships? Retrieved from http://www.scielo.br/pdf/bar/v11n4/1807-7692-bar-11-04-00476

Lindsey, A., King, E., Hebl, M., \& Levine, N. (2015). The impact of method, motivation, and empathy on diversity training effectiveness. Journal of Business \& Psychology, 30(3), 605-617.

Mubarki, S. (2014). The role of the human performance management in achieving the job satisfaction at the organization: The Municipal Assembly of Biskra as a case study. Master Thesis, Mohammed Khaydar University, Biskra, Algeria.

Munjuri, M. (2012). Workforce diversity management and employee performance in the banking sector in Kenya, 
DBA Africa Management Review, 3(1), 1-21.

Mursi, S. (2010). Cultural diversity in the multinational organizations and its reflections on the human development strategies. Journal of Administrative Research, 28(3), 100-135.

Na-Nan, K., \& Pukkeeree, P. (2013). Influence of job characteristics and job satisfaction effect work adjustment for entering labor market of new graduates in Thailand. International Journal of Business and Social Science, 4(2), 95-103.

Ogunnaike, O., \& Akinbola, O. (2014). Effect of motivation on job satisfaction of selected sales representatives.

Punia, B., \& Kant, S. (2013). A review of factors affecting training effectiveness vis-à-vis managerial implications and future research directions.

Roos, W. (2005). The relationship between employee motivation, job satisfaction and corporate culture. Retrieved from http://uir.unisa.ac.za/bitstream/ handle/ $10500 / 2584 /$ ?sequence $=36$

Saks, A. \& Haccoun, R. (2007). Managing performance through training and development, Toronto, Nelson and Thompson Ltd.

Saleem, R., Mahmood, A., \& Mahmood, A. (2010). Effect of work motivation on job satisfaction in mobile telecommunication service organizations of Pakistan. International Journal of Business and Management, $5(11), 213-222$.

Sohail, A., Ur Rehman, K., Ul Haq, Sh., Iqbal, J., Razaq, A., \& Sabir, S. (2011). The impact of diversity training on commitment, career satisfaction and innovation. Retrieved from https://mpra.ub.uni-muenchen.de/53852/1/MPRA_paper_53852

Tai, W. (2006). Effects of training framing, general self-efficacy and training motivation on trainees' training effectiveness. Personnel Review, 35(1), 51-65.

Yap, M., \& Holmes, M. (2010). The relationship between diversity training, organizational commitment, and career satisfaction. Journal of European Industrial Training. Retrieved from http://www.emeraldinsight.com/doi/pdfplus/10.1108

Yousef, M. (2010). Motivation and its impact on the job satisfaction among employees in the industrial sector entities at the industrial city in Makkah. British Arab Academy for Higher Education. http://www.abahe.co.uk/Research-Papers/Motivation-and-its-impact-in-achieving-job-satisfaction.pdf

Zarzoor, B. (2015). Cultural diversity management inside organizations: Opportunities and challenges - WHO as a case study. Eighth International Conference (Cultural Diversity), Tripoli, Algeria.

Zwiesh, S. (2014). the determinants of the job satisfaction and their impact on the performance of employees at the organization: Amzil Amhamed Bheizar high school as a case study. Master Thesis, Akli Mohand Oulhaj University, Al-Bouira, Algeria.

\section{Appendix 1.}

The Study Questionnaire

Part I: personal and functional data:

Please answer the following questions, and tick $(\checkmark)$ in the box where the category represents your viewpoint.

1- Nationality:

2- The language you speak in your country:

3- Religion

4- Gender

$\square$ Male $\square$ Female

5- Marital status:

$\square$ Single $\square$ Married $\square$ otherwise.

6- Age:

Less than 25 years $\square$ 25- less than $30 \square$ 30- 45 years $\square 45$ years and above 


\section{7- Scientific Qualification:}

$\square$ High school or less $\square$ Diploma Bachelor $\square$ Master Ph.D.

\section{8- Job title:}

$\square$ Director / Deputy Director $\square$ head of the Department Overseer.

\section{9- years of Experience:}

$\square$ Less than 5 years $\square 5$ to 10 years $\square$ 11-less than 15 years $\square 15$ years and above.

\section{0- The number of training courses in diversity training you had during your job in the company:}

None

one

three and above

Part II : this section reflects your assessment for the level of practicing the diversity training in your company, so tick $(\checkmark)$ in the box where the category represents your viewpoint.

\begin{tabular}{|c|c|c|c|c|}
\hline Number Item & $\begin{array}{l}\text { Very } \\
\text { strongly } \\
\text { agree }\end{array}$ & $\begin{array}{l}\text { Strongly } \\
\text { agree }\end{array}$ & $\begin{array}{l}\text { Moderately } \\
\text { agree }\end{array}$ & $\begin{array}{ll}\text { Agree by a } & \begin{array}{l}\text { Agree by a } \\
\text { very low } \\
\text { low degree }\end{array} \\
\text { degree } & \end{array}$ \\
\hline
\end{tabular}

1. The company's management is formally committed to teaching its employees about the nature of workforce diversity.

2. The company's management encourages discussion among employees about the nature of workforce diversity.

3. The Company's management determines the training needs related to the diversity training.

4. When determining the employees' needs for the training diversity, the company's management takes into account the extent of employees' acceptance for this kind of training.

5. The company's management gives importance to the issue of workforce diversity when formulating its vision and mission.

6. The company's management is keen to ensure diversity training within the plans of the training organization.

7. The company's management is keen to show topics on workforce diversity on the company's website.

8. The training programs in the company are designed in line with the company's strategy.

9. the content of the training material for the diversity training programs is putting in light of the needs of its employees.

10. when choosing those responsible for preparing the programs of diversity training, the availability of vast experience in the field of workforce diversity is taken into consideration.

11. when choosing those responsible for executing the programs of diversity training, the availability of the required skills is taken into consideration.

12. the objectives and requirements of the training program are explained to the trainees.

13. Issues of cultural diversity are included within the training programs held by the company to its employees.

14. The diversity training programs held by the company are difficult since they discuss uncomfortable issues such as discrimination.

15. The company provides training programs to grant non-Arab employees the language of the host country.

16. The company holds training programs to equip its Arab employees with the languages spoken by their colleagues of other nationalities. 
17. The training programs include enough information about the values, customs and traditions of the Jordanian society.

18. The training programs offered by the company help create social relationships and interaction among trainees.

19. All material supplies needed by the process of implementing diversity training programs are provided.

20. Diversity training programs held by the company contribute to increase respect and appreciation among employees of different races.

21. Diversity training programs held by the company contribute to increase respect and appreciation among employees of different ages.

22. Diversity training programs held by the company contribute to increase respect and appreciation among employees whether males or females.

23. The company's management distribute forms to the trainees to learn their viewpoints on the effectiveness of diversity training program after the end of training.

24. The company's management conducts written tests for the trainees after the end of the diversity training program to see how they benefited from this program.

25. The Company's management follows up the trainees' complaints provided to the trainers on the diversity training programs.

26. The company's management forms internal committees that follows up the level of the implementation of the diversity training programs.

27. the company's management uses external evaluators to assess the ability of the diversity training programs to bring about the desired changes in the behavior of trainees.

28. Thecompany's management observes the level of dealing with tolerance among its employees after they were subjected to diversity training programs.

29. TheCompany's management observes the quality of communication and dialogue held among its employees after being subjected to diversity training programs.

Part III: This part reflects your evaluation of the level of your sense of job satisfaction, so tick $(\checkmark)$ in the box where the category represents your viewpoint.

\begin{tabular}{|c|c|c|c|c|c|c|}
\hline \multicolumn{2}{|c|}{ Number Item } & \multirow{2}{*}{$\begin{array}{l}\begin{array}{l}\text { Very } \\
\text { strongly } \\
\text { agree }\end{array} \\
\end{array}$} & \multirow[t]{2}{*}{$\begin{array}{l}\text { Strongly } \\
\text { agree }\end{array}$} & \multirow[t]{2}{*}{$\begin{array}{l}\text { Moderately } \\
\text { agree }\end{array}$} & \multirow{2}{*}{\multicolumn{2}{|c|}{$\begin{array}{l}\text { Agree by a Agree by a very } \\
\text { low degree low degree }\end{array}$}} \\
\hline 30. & $\begin{array}{l}\text { I feel satisfied for the way the job is organized within the } \\
\text { company. }\end{array}$ & & & & & \\
\hline 31. & $\begin{array}{l}\text { The job hours are appropriate and they are consistent with } \\
\text { the nature of my work. }\end{array}$ & & & & & \\
\hline 32. & My superiors appreciate my efforts in my job. & & & & & \\
\hline 33. & $\begin{array}{l}\text { My boss entrusts me with powers that enable me to make } \\
\text { decisions about my job. }\end{array}$ & & & & & \\
\hline 34. & $\begin{array}{l}\text { Between my colleagues and } \mathrm{I} \text {, there are friendly } \\
\text { relationships based on mutual respect. }\end{array}$ & & & & & \\
\hline 35. & $\begin{array}{l}\text { My colleagues help me in the fields related to the } \\
\text { performance of my duties. }\end{array}$ & & & & & \\
\hline 36. & My manager is keen to distribute the additional job tasks & & & & & \\
\hline
\end{tabular}


equally among employees.

37. My manager is keen to listen to my views and suggestions that aim to improve the job.

38. The company's management offers the possibility to contact it any time and without any hindrance.

39. The company's management provides information that I may need at work as soon as possible.

40. My salary is suitable with my performance.

41. the incentives granted to me suits the extra effort I do at work.

42. Rewards are distributed fairly among the employees of the company.

43. Promotion in my company is based on the efficiency of the performance.

44. At my job, all the physical conditions (ventilation, lighting, heat, and cleanness) are providing me with comfort .

Part IV: This section reflects your evaluation of the level of organizational commitment of employees in the company, so tick $(\checkmark)$ in the box where the category represents your viewpoint.

\begin{tabular}{|c|c|c|c|c|c|}
\hline \multicolumn{2}{|c|}{ Number Item } & \multirow[t]{2}{*}{$\begin{array}{l}\text { Very strongly Strongly } \\
\text { agree } \quad \text { agree }\end{array}$} & \multirow[t]{2}{*}{$\begin{array}{l}\text { Moderately } \\
\text { agree }\end{array}$} & \multirow[t]{2}{*}{$\begin{array}{l}\text { Agree by } \\
\text { low degree }\end{array}$} & \multirow[t]{2}{*}{$\begin{array}{l}\text { a Agree by a very } \\
\text { low degree }\end{array}$} \\
\hline 45. & I feel proud of being one of the company's employees. & & & & \\
\hline 46. & $\begin{array}{l}\text { I consider the company's problems my personal } \\
\text { problems. }\end{array}$ & & & & \\
\hline 47. & $\begin{array}{l}\text { I feel like I'm among my family members in the } \\
\text { company where I work. }\end{array}$ & & & & \\
\hline 48. & $\begin{array}{l}\text { I feel that my personal values are consistent with the } \\
\text { company's personal values. }\end{array}$ & & & & \\
\hline 49. & $\begin{array}{l}\text { my company deserves sincerity and loyalty by } \\
\text { employees. }\end{array}$ & & & & \\
\hline 50. & $\begin{array}{l}\text { I feel that the process of transition from one company to } \\
\text { another for work is unethical. }\end{array}$ & & & & \\
\hline 51. & $\begin{array}{l}\text { I want to stay at the company regardless of other } \\
\text { alternative employment opportunities. }\end{array}$ & & & & \\
\hline 52. & $\begin{array}{l}\text { My commitment to work at the company is because of } \\
\text { the friendship that I have had with my colleagues. }\end{array}$ & & & & \\
\hline 53. & $\begin{array}{l}\text { My presence in my current work is a good functional } \\
\text { investment to me. }\end{array}$ & & & & \\
\hline 54. & $\begin{array}{l}\text { The reason for staying at my job in the company is the } \\
\text { good reputation enjoyed by it in the community. }\end{array}$ & & & & \\
\hline 55. & $\begin{array}{l}\text { I owe the company because of the functional privileges } \\
\text { granted to me. }\end{array}$ & & & & \\
\hline 56. & $\begin{array}{l}\text { I agree to be entrusted with any job in the company in } \\
\text { exchange for staying there. }\end{array}$ & & & & \\
\hline 57. & $\begin{array}{l}\text { My transition to work at another company will cost me } \\
\text { the loss of many functional advantages. }\end{array}$ & & & & \\
\hline 58. & $\begin{array}{l}\text { I strongly care for the future of the company where I } \\
\text { work. }\end{array}$ & & & & \\
\hline 59. & $\begin{array}{l}\text { I look forward to get a tidy and functional outstanding in } \\
\text { the company. }\end{array}$ & & & & \\
\hline 60. & $\begin{array}{l}\text { I'd be happy if I spend the rest of my life in the company } \\
\text { where I work. }\end{array}$ & & & & \\
\hline
\end{tabular}




\section{Copyrights}

Copyright for this article is retained by the author(s), with first publication rights granted to the journal.

This is an open-access article distributed under the terms and conditions of the Creative Commons Attribution license (http://creativecommons.org/licenses/by/4.0/). 